UCRL-JC-122362

PREPRINT

\title{
An Intermediate Temperature Modeling Study of the Combustion of Neopentane
}

\author{
H.J. Curran \\ W.J. Pitz \\ C.K. Westbrook
}

RECEIVED

NOV -31995

OSTI

This was prepared for submittal to the

Proceedings of the 1995 Fall Meeting

of the Western State Section

of the Combustion Institute

Stanford University

Stanford, California

October 30-31, 1995

October 1995

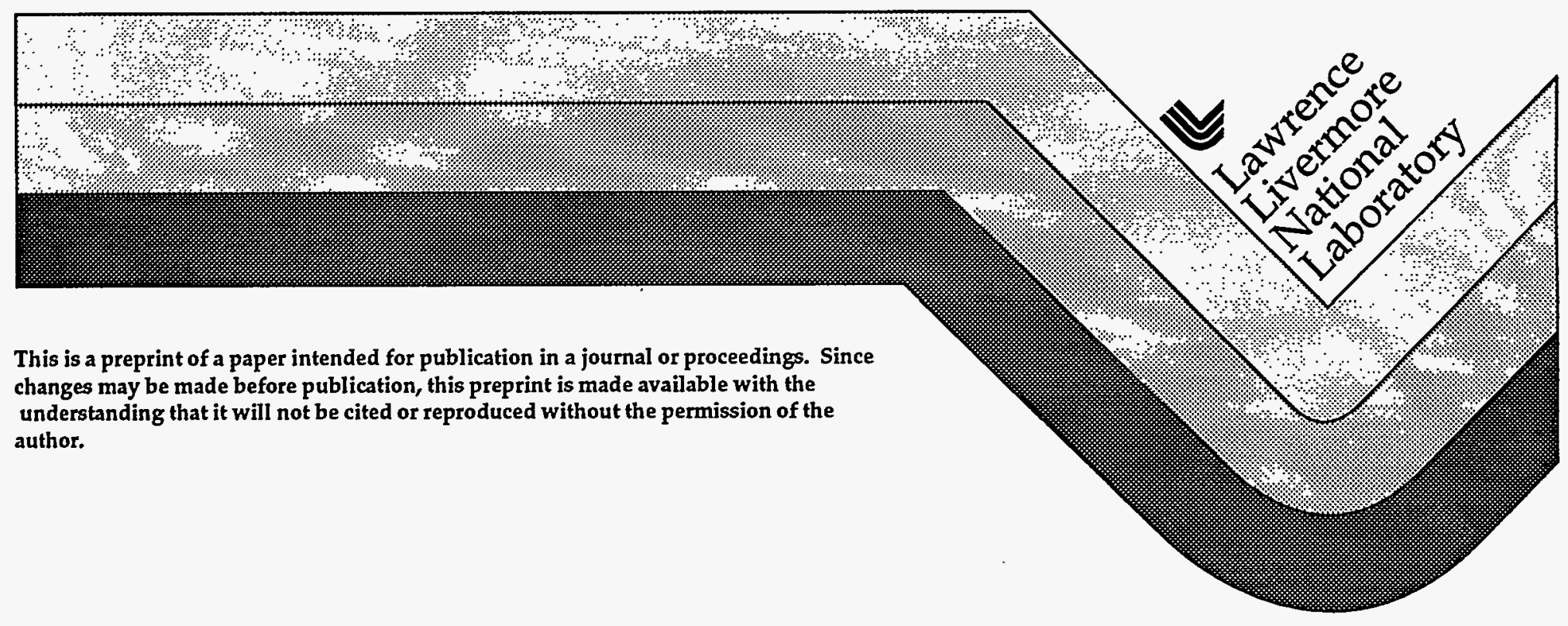

This is a preprint of a paper intended for publication in a journal or proceedings. Since changes may be made before publication, this preprint is made available with the understanding that it will not be cited or reproduced without the permission of the author. 


\section{DISCLAIMER}

This document was prepared as an account of work sponsored by an agency of the United States Government. Neither the United States Government nor the University of Californiz nor any of their employees, makes any warranty, express or implied, or assumes anylegal liability or responsibility for the accuracy, completeness, or usefulness of any information, apparatus, product, or process disdosed, or represents that its use would not infringeprivately owned rights. Reference herein to any specific commercial products, process, or service by trade name, trademark, manufacturer, or otherwise, does not necessarily constitute or imply its endorsement, recommendation, or favoring by the United States Government or the University of California. The views and opinions of authors expressed herein do not necessarily state or reflect those of the United States Government or the University of Califormia, and shall not be used for advertising or product endorsement purposes. 


\title{
An Intermediate Temperature Modeling Study of the Combustion of Neopentane.
}

\author{
H. J. Curran, W. J. Pitz, C. K. Westbrook \\ Lawrence Livermore National Laboratory, Livermore, CA 94550
}

\begin{abstract}
A detailed chemical kinetic reaction mechanism is used to study the oxidation of neopentane in a closed reactor at 500 Torr pressure, and at a temperature of $753 \mathrm{~K}$ when small amounts of neopentane are added to slowly reacting mixtures of $\mathrm{H}_{2}+\mathrm{O}_{2}+\mathrm{N}_{2}$. The major primary products formed in the experiments included isobutene, 3,3-dimethyloxetan, acetone, methane and formaldehyde. The major secondary products were, 2,2-dimethyloxiran, propene, isobuteraldehyde, methacrolein, and 2-methylprop-2-en-1-ol. It was found that the current model was able to explain both primary and secondary product formation with a high degree of accuracy. Furthermore, it was found that almost all secondary product formation could be explained through the oxidation of isobutene-a major primary product.
\end{abstract}

\section{Introduction}

Low temperature hydrocarbon fuel oxidation proceeds via straight and branched chain reactions involving alkyl and alkyl peroxy radicals. These reactions play a critical role in the chemistry leading to "knock" or autoignition in spark ignition engines [1]. As part of an on-going study in the understanding of low temperature oxidation of hydrocarbon fuels, we have investigated neopentane oxidation. The mechanism of neopentane oxidation involves two relatively unique features. Firstly, in the oxidation of simple hydrocarbons such as ethane or propane, for example, formation of the conjugate olefin is the dominant reaction of the alkyl radical at $700-800 \mathrm{~K}$, but this reaction is not possible for the neopentyl radical and thus reactions which occur infrequently for other hydrocarbons are increased in importance in the case of neopentane. Secondly, because all the 
hydrogen atoms in neopentane are equivalent, only one type of alkyl radical is produced. Similarly, throughout the recognised low temperature oxidation sequence only one particular species is formed leading to a simplified reaction scheme in which reaction pathways can be traced with relative ease.

The oxidation of neopentane has been investigated by several workers [2]-[6] over the temperature range 533-623 $\mathrm{K}$ but these papers reported qualitative rather than quantitative aspects of the reaction mechanism. Zeelenberg [2] examined the products formed during the early stages of reaction at $533 \mathrm{~K}$ but results are reported for only one mixture composition. Antonik and Lucquin [3] studied the cool-flame and explosion limits, and also carried out a partial analysis of the products in the presence and absence of $\mathrm{HBr}$ at $563 \mathrm{~K}$ [4]. Drysdale and Norrish [5] determined the products over a wide extent of reaction at $553 \mathrm{~K}$, but the results are limited to one mixture and appear incomplete; for instance, the yield of the cyclic ether 3,3-dimethyloxetan is not given even though it is one of the major primary products of neopentane oxidation. Fish [6] carried out a study of both the cool-flame and two-stage ignition of neopentane-oxygen mixtures in the temperature range $573-623 \mathrm{~K}$, but gave only a qualitative distribution of products.

Baker et al. $[7,8]$ have studied the oxidation of neopentane by adding small quantities of neopentane fuel to slowly reacting mixtures of hydrogen and oxygen at $753 \mathrm{~K}$. They report a complete analysis of the products (except $\mathrm{H}_{2} \mathrm{O}$ and peroxide species) at 500 Torr total pressure for

-. two mixtures containing 5 Torr of neopentane; one of high $\mathrm{O}_{2}$ content $\left(\mathrm{H}_{2}=140, \mathrm{O}_{2}=355\right.$ Torr $)$ and one of high $\mathrm{H}_{2}$ content $\left(\mathrm{H}_{2}=425, \mathrm{O}_{2}=70\right.$ Torr $)$. In the present work we have attemped to model the results of Baker et al. [7, 8] as these are the most complete set of data in the literature and as such would be the most extensive test of the model. This study is unique in that there has not as yet been a publication in which a detailed reaction mechanism has been used to explain neopentane oxidation. It is intended that the mechanism will be used over a more broad range of conditions in the near future. 


\section{Computational Model}

All of the modelling computations in this study were carried out using the HCT modelling code [9]. This code permits the use of a variety of boundary and initial conditions for reactive systems depending on the needs of the particular system being examined. In the present case, the relevant conditions are those which describe the bulk gases in a static reactor-conditions of constant volume and temperature. The detailed chemical kinetic reaction mechanism used in these calculations was based on previous work by the authors $[10]-[14]$, and on the hierarchical nature of reacting systems starting with a core mechanism describing $\mathrm{H}_{2} / \mathrm{O}_{2}$ and $\mathrm{CO}$ oxidation. To this is added the progressively larger $C_{1}-C_{4}$ mechanism and ultimately the $C_{5}$ neopentane mechanism whereby the model consists of approximately 310 different chemical species and 1570 elementary reactions.

In our more recent modelling work $[13,14]$ we have described the use of particular rules which we have applied to the low temperature oxidation mechanism. These have been applied to the current mechanism although we have used experimentally determined rate constants wherever possible. In addition, the thermodynamic properties for the relevant radicals and stable parents were obtained by group additivity using THERM [15] with updated $\mathrm{H} / \mathrm{C} / \mathrm{O}$ groups and bond dissociation groups [16]. The thermochemical data allow calculation of reverse reaction rate constants by microscopic reversibility. A full listing of the reaction mechanism can be obtained by Internet electronic mail (curran6@llnl.gov) or on disk by writing to the authors.

\section{Neopentane Oxidation}

The overall reaction scheme for neopentane oxidation can be depicted as follows,

$$
\begin{aligned}
\text { neoC }_{5} \mathrm{H}_{12} & \longrightarrow \text { neoC }_{5} \mathrm{H}_{11}+\mathrm{HX} \\
\text { neoC }_{5} \mathrm{H}_{11} & \stackrel{493}{\longrightarrow} \mathrm{iC}_{4} \mathrm{H}_{8}+\mathrm{CH}_{3} \\
\text { neoC }_{5} \mathrm{H}_{11}+\mathrm{O}_{2} & \stackrel{-13 f^{3}}{\rightleftharpoons} \text { neoC }_{5} \mathrm{H}_{11} \mathrm{O}_{2}
\end{aligned}
$$




$$
\begin{aligned}
\text { neoC }_{5} \mathrm{H}_{11} \mathrm{O}_{2} & \stackrel{1315}{\rightleftharpoons} \mathrm{neoC}_{5} \mathrm{H}_{10} \mathrm{OOH} \\
\text { neoC }_{5} \mathrm{H}_{10} \mathrm{OOH} & \stackrel{1322}{\longrightarrow} \mathrm{neoC}_{5} \mathrm{H}_{10} \mathrm{O}+\mathrm{OH} \\
\text { neoC } \mathrm{H}_{10} \mathrm{OOH} & \stackrel{1323}{\longrightarrow} \mathrm{iC}_{4} \mathrm{H}_{8}+\mathrm{CH}_{2} \mathrm{O}+\mathrm{OH} \\
\text { neoC }_{5} \mathrm{H}_{10} \mathrm{OOH} & \stackrel{1467}{\longrightarrow} \mathrm{iC}_{4} \mathrm{H}_{7} \mathrm{OOH}+\mathrm{CH}_{3} \\
\mathrm{neoC}_{5} \mathrm{H}_{10} \mathrm{OOH}+\mathrm{O}_{2} & \stackrel{-1324}{\rightleftharpoons} \mathrm{O}_{2} \mathrm{neoC}_{5} \mathrm{H}_{10} \mathrm{OOH} \\
\mathrm{O}_{2} \mathrm{neoC}_{5} \mathrm{H}_{10} \mathrm{OOH} & \stackrel{1325}{\rightleftharpoons} \mathrm{neoC}_{5} \mathrm{ket}+\mathrm{OH} \\
\text { neoC } & \stackrel{1434}{\longrightarrow} \mathrm{iC}_{3} \mathrm{H}_{6} \mathrm{CHO}+\mathrm{CH}_{2} \mathrm{O}+\mathrm{OH}
\end{aligned}
$$

where the reaction numbers refer to those in our current reaction mechanism. The species names are defined as follows: neoC $_{5} \mathrm{H}_{11}$ (nepentyl), $\mathrm{iC}_{4} \mathrm{H}_{8}$ (isobutene), neo $\mathrm{C}_{5} \mathrm{H}_{11} \mathrm{O}_{2}$ (neopentylperoxy), neoC $\mathrm{H}_{10} \mathrm{OOH}$ (hydroperoxy-neopentyl), neoC $\mathrm{H}_{10} \mathrm{O}$ (3,3-dimethyloxetan), $\mathrm{iC}_{4} \mathrm{H}_{7} \mathrm{OOH}$ (isobutenylhydroperoxide), $\mathrm{O}_{2} \mathrm{neoC}_{5} \mathrm{H}_{10} \mathrm{OOH}$ (hydroperoxy-neopentylperoxy radical) and neoC $\mathrm{C}_{5}$ ket (neopentylketohydroperoxide). As noted above, the unique molecular structure of neopentane leads to the fact that there is only one isomer of each of the above $\mathrm{C}_{5}$ stable and radical species, and there is only one isomerization reaction possible for both the $\mathrm{RO}_{2}$ and $\mathrm{O}_{2} \mathrm{QOOH}$ radicals.

At high temperatures, the fuel consumption pathway is quite simple, with $\beta$-scission of the neopentyl radical proceeding rapidly to isobutene and methyl radical, and chain branching due primarily to the reaction $\mathrm{H}+\mathrm{O}_{2} \rightleftharpoons \mathrm{O}+\mathrm{OH}$. However, at low temperatures, chain branching is due primarily to the reaction pathway leading through the ketohydroperoxide species. As the temperature increases, the chain propagation reactions of alkylhydroperoxide species also increase, leading to the formation of heterocyclic species, olefins, and other $\beta$-decomposition products. The present study was carried out at an intermediate temperature of $753 \mathrm{~K}$, and thus both low and high temperature chemistry contribute to fuel oxidation. 
In this study initiation occurs via the following three reactions,

$$
\begin{aligned}
\text { neoC }_{5} \mathrm{H}_{12}+\mathrm{O}_{2} & \stackrel{490}{\longrightarrow} \mathrm{neoC}_{5} \mathrm{H}_{11}+\mathrm{HO}_{2} \\
\mathrm{H}_{2}+\mathrm{O}_{2} & \stackrel{-48}{\longrightarrow} \mathrm{HO}_{2}+\mathrm{H} \\
\text { neoC }_{5} \mathrm{H}_{12} & \stackrel{490}{\longrightarrow} \mathrm{tC}_{4} \mathrm{H}_{9}+\mathrm{CH}_{3}
\end{aligned}
$$

This is followed by $\mathrm{H}$-atom abstraction from the fuel, primarily by $\mathrm{OH}$ and $\mathrm{H}$ atoms and to a lesser extent by $\mathrm{CH}_{3}, \mathrm{HO}_{2}, \mathrm{O}, \mathrm{CH}_{3} \mathrm{O}_{2}$ and $\mathrm{O}_{2}$. The neopentyl radical so produced, can either add with molecular oxygen to produce neopentylperoxy radicals, neoC $\mathrm{H}_{11} \mathrm{O}_{2}$, or undergo $\beta$-scission to give isobutene and methyl radicals. The rate of $\mathrm{O}_{2}$ addition to neopentyl radical was taken from Xi et al. [17] while the rate of neopentyl $\beta$-scission, reaction (493), was taken from the study of Slagle et al. [18] which reported a limiting high-pressure Arrhenius expression in addition to a fall-off analysis for this reaction. The rate of this $\beta$-scission reaction, including the fall-off fit applicable to the current experimental conditions is given in Table 1 together with the comparable values recommended by Hughes et al. [19, 20] and Baldwin et al. [21].

\section{Reactions of Neopentylperoxyl Species}

Reactions of the neoC $\mathrm{C}_{5} \mathrm{H}_{11} \mathrm{O}_{2}$ species and the equilibrium of the $\mathrm{R}+\mathrm{O}_{2} \rightleftharpoons \mathrm{RO}_{2}$ reaction are of great importance in determining both the product species distributions and the overall rate of fuel oxidation. There are three major types of reactions of the $\mathrm{neoC}_{5} \mathrm{H}_{11} \mathrm{O}_{2}$ radicals.

1. Decomposition to neoC $\mathrm{H}_{11}+\mathrm{O}_{2}$. This rate is calculated from the equilibrium constant for the $\mathrm{neoC}_{5} \mathrm{H}_{11}+\mathrm{O}_{2} \stackrel{-1313}{\rightleftharpoons}$ neoC $_{5} \mathrm{H}_{11} \mathrm{O}_{2}$ reaction and from thermochemistry. The equilibrium constant $\mathrm{K}_{\mathrm{eq}}$ for this reaction, is reported in Table 1 together with the corresponding values recommended by Hughes et al. $[19,20]$ and Baldwin et al. [21]. The present value of $K_{-1313}$ is consistent with recent values of $\mathrm{H}_{298}$ and $\mathrm{S}_{298}$ for the neopentyl radical.

2. Intermolecular abstraction of hydrogen atoms from other hydrocarbon species to produce 
neopentylhydroperoxide radical, (neoC $\left.\mathrm{H}_{11} \mathrm{OOH}\right)$, which then decomposes to neoC $_{5} \mathrm{H}_{11} \mathrm{O}+$ $\mathrm{OH}$, followed by reactions of the $\mathrm{RO}$ radical. This sequence of reactions is of relatively minor importance in this study.

3. The most important step involves isomerization of the neoC $\mathrm{C}_{5} \mathrm{H}_{11} \mathrm{O}_{2}$ radical via internal $\mathrm{H}$ atom transfer to form hydroperoxy-neopentyl radical, neoC $\mathrm{H}_{10} \mathrm{OOH}$. A more in-depth description of this type of reaction has been given previously [10]-[14], with the rate for the isomerization presented in Table 1.

As seen in Table 1 our recommended rate for this reaction is approximately sixty times faster than that reported by Hughes and coworkers $[19,20]$ and almost six times faster than the rate recommended by Baldwin et al. [21]. However, in the studies by both Hughes and co-workers and Baldwin et al. it is assumed that there is no reverse isomerization (i.e. there is no formation of neopentylperoxy radical from hydroperoxy-neopentyl). However, examination of output from our mechanism calculations indicates that an equilibrium develops between the $\mathrm{ROO} \rightleftharpoons \mathrm{QOOH}$ species and that there is quite a significant rate of reverse isomerization. In addition, Hughes et al. [19] have indicated that their recommended value for neopentylperoxyl radical isomerization is over an order of magnitude smaller than that determined indirectly by Baldwin et al. [21]. They explain this discrepency from the use by Baldwin et al. of an inaccurate estimate for the equilibrium neoC $\mathrm{H}_{11}+\mathrm{O}_{2} \rightleftharpoons \mathrm{neoC}_{5} \mathrm{H}_{11} \mathrm{O}_{2}$.

\begin{tabular}{|lccc|}
\hline $\mathrm{T}=700 \mathrm{~K}$ & Ref. $[19,20]$ & Ref. [21] & This work \\
\hline \hline $\mathrm{k}_{493}\left(\mathrm{~s}^{-1}\right)$ & $1.56 \times 10^{+04}$ & $1.39 \times 10^{+04}$ & $8.92 \times 10^{+03}$ \\
$\mathrm{~K}_{-1313}\left(\mathrm{~cm}^{3}\right.$ molecule $\left.^{-1}\right)$ & $3.89 \times 10^{-17}$ & $3.12 \times 10^{-18}$ & $4.25 \times 10^{-17}$ \\
$\mathrm{k}_{1315}\left(\mathrm{~s}^{-1}\right)$ & $1.24 . \times 10^{+03}$ & $1.33 \times 10^{+04}$ & $7.66 \times 10^{+04}$ \\
\hline
\end{tabular}

Table 1: Comparison of current model rates with literature recommendations 


\section{Reactions of QOOH Species.}

The neopentylhydroperoxide (QOOH) species formed can react via three major pathways.

1. Following Pollard [22], this species can react via O-O homolysis, producing the cyclic ether, 3,3-dimethyloxetan, and hydroxyl radical. The rate parameters for this reaction are given in Table 2 and are consistent with those reported in an earlier publication [14] for the formation of oxetan species from an alkylhydroperoixde radical.

2. The neoC $\mathrm{H}_{10} \mathrm{OOH}$ species which has an intermediate ring structure of six atoms can undergo $\beta$-scission. This reaction can occur at two different sites leading to the formation of two distinct sets of products. The hydroperoxy-neopentyl radical may scission to yield isobutene, formaldehyde and hydroxyl radical but can also lead to an alternative set of products, isobutenylhydroperoxide, $\mathrm{iC}_{4} \mathrm{H}_{7} \mathrm{OOH}$, and methyl radical. The rate for the formation of both sets of products was determined as follows. The reverse rate (i.e. either isobutene plus hydroperoxy-methyl radical or isobutenylhydroperoxide plus methyl radical) was likened to a methyl radical adding across the double bond in isobutene to yield neopentyl radical. The rate for this reaction was taken from Slagle et al. [18] to be $2.23 \times 10^{11} \exp (-10600 / \mathrm{RT})$. Both forward rates, the $\beta$-scission reactions, were calculated using a THERMRXN [15] analysis, Table 2.

3. In addition, $\mathrm{QOOH}$ can react with molecular oxygen to form neopentylperoxylhydroperoxide, $\mathrm{O}_{2} \mathrm{neoC}_{5} \mathrm{H}_{10} \mathrm{OOH}$, species. The rate of this reaction was taken to be equal to that used for the addition of $\mathrm{O}_{2}$ to neopentyl radical.

An important aspect of the present mechanism is in the consideration of the fate of the peroxyneopentyl-hydroperoxide, $\mathrm{O}_{2}$ neoC $\mathrm{H}_{5} \mathrm{H}_{10} \mathrm{OOH}$ species formed. As discussed in an earlier publication [14], and in recognition of experimental observations by Sahetchian et al. [23] in which heptyl- 


\begin{tabular}{|c|c|c|c|c|}
\hline No. & Reaction & $\mathcal{A}$ & $n$ & $\varepsilon_{a}$ \\
\hline-1313 & neoC $_{5} \mathrm{H}_{11}+\mathrm{O}_{2}=$ neoC $_{5} \mathrm{H}_{11} \mathrm{O}_{2}$ & $1.990 \mathrm{E}+17$ & -2.10 & 0. \\
\hline 1315 & $\mathrm{neoC}_{5} \mathrm{H}_{11} \mathrm{O}_{2}=\mathrm{neoC}_{5} \mathrm{H}_{10} \mathrm{OOH}$ & $2.470 \mathrm{E}+11$ & 0.00 & 23900. \\
\hline 1322 & $\mathrm{neoC}_{5} \mathrm{H}_{10} \mathrm{OOH}=\operatorname{neoC}_{5} \mathrm{H}_{10} \mathrm{O}+\mathrm{OH}$ & $2.500 \mathrm{E}+10$ & 0.00 & 15250. \\
\hline 1323 & $\mathrm{neoC}_{5} \mathrm{H}_{10} \mathrm{OOH}=\mathrm{iC}_{4} \mathrm{H}_{8}+\mathrm{CH}_{2} \mathrm{O}+\mathrm{OH}$ & $5.000 \mathrm{E}+13$ & 0.00 & 29000. \\
\hline 1467 & $\mathrm{neoC}_{5} \mathrm{H}_{10} \mathrm{OOH}=\mathrm{iC}_{4} \mathrm{H}_{7} \mathrm{OOH}+\mathrm{CH}_{3}$ & $1.000 \mathrm{E}+13$ & 0.00 & 29000 . \\
\hline-1324 & ${ }_{n e o C} \mathrm{H}_{10} \mathrm{OOH}+\mathrm{O}_{2}=\mathrm{O}_{2}$ neoC $_{5} \mathrm{H}_{10} \mathrm{OOH}$ & $1.990 \mathrm{E}+17$ & -2.10 & 0 . \\
\hline 1325 & $\mathrm{O}_{2}$ neoC $\mathrm{C}_{5} \mathrm{H}_{10} \mathrm{OOH}=$ neoC $_{5}$ ket $+\mathrm{OH}$ & $1.240 \mathrm{E}+11$ & 0.00 & 20900. \\
\hline 1434 & neoC ${ }_{5}$ ket $=\mathrm{iC}_{3} \mathrm{H}_{6} \mathrm{CHO}+\mathrm{CH}_{2} \mathrm{O}+\mathrm{OH}$ & $1.000 \mathrm{E}+16$ & 0.00 & 43000 . \\
\hline
\end{tabular}

Table 2: Rate expressions for critical reactions in neopentane oxidation; $\mathrm{cm}^{3} / \mathrm{mol} / \mathrm{sec} / \mathrm{cal}$ units.

ketohydroperoxides are observed, we include a mechanistic step in which the $\mathrm{O}_{2} \mathrm{QOOH}$ radical isomerizes, releasing $\mathrm{OH}$ and producing a ketohydroperoxide species. The rates for this isomerization via an internal $\mathrm{H}$ atom transfer, presented in Table 2, is analogous to that for $\mathrm{RO}_{2} \rightleftharpoons \mathrm{QOOH}$ isomerization. However, the activation energy has been reduced by $3 \mathrm{kcal} \mathrm{mol}^{-1}$ as the $\mathrm{H}$ atom being abstracted is bound to a $\mathrm{C}$ atom which is bound to a hydroperoxy group and should be more easily removed. In addition, the $\mathcal{A}$-factor has also been reduced by a factor of 0.5 considering'steric hinderance due to the $\mathrm{OOH}$ group.

Finally, the decomposition of ketohydroperoxide molecules leads to the formation of two radicals: an $\mathrm{OH}$ radical and a very important resonantly stabilized carbonyl radical, $\mathrm{iC}_{3} \mathrm{H}_{6} \mathrm{CHO}$ $\left(\mathrm{H}_{3} \mathrm{C}-\dot{\mathrm{C}}\left(\mathrm{CH}_{3}\right)-\mathrm{CH}=\mathrm{O}\right)$, in addition to a stable formaldehyde product.

$$
\mathrm{HOOH}_{2} \mathrm{C}-\mathrm{C}-\left(\mathrm{CH}_{3}\right)_{2}-\mathrm{CH}=\mathrm{O} \stackrel{1434}{\longrightarrow} \mathrm{H}_{3} \mathrm{C}-\dot{\mathrm{C}}\left(\mathrm{CH}_{3}\right)-\mathrm{CH}=\mathrm{O}+\mathrm{CH}_{2} \mathrm{O}+\mathrm{OH}
$$

This is considered a chain branching reaction. A rate of $1 \times 10^{16} \exp (-43000 / R T)$. was estimated previously for the the decomposition all ketohydroperoxide species having greater than four carbon atoms. The pre-exponential $\mathcal{A}$-factor is based on the value for the unimolecular decomposition of a molecule [24], and the activation energy, $\mathcal{E}_{a}$ is based on $\left(\Delta \mathrm{U}^{\prime}=\Delta \mathrm{H}-\mathrm{RT}\right)$ for the reaction. The rate 
of this reaction controls the induction period at low temperatures because its high activation energy ensures a build up of large quantities of ketohydroperoxide, which reaches a critical concentration and decomposes leading to chain branching. This feature was not properly reproduced in out past modelling analysis [10]-[12], in which the $\mathrm{O}_{2} \mathrm{QOOH}$ decomposition had been assumed to decompose to smaller products immediately.

\section{Modelling Results}

In this section, the product species concentrations calculated by the model and measured in the experiment [7] are discussed and compared. The product species results of the model and the experiment are shown in Figures 1-2 for the two different mixtures.

\section{Primary Product Formation}

At $753 \mathrm{~K}$ ( $\leq 10 \%$ fuel conversion) the primary products are isobutene $\left(\mathrm{iC}_{4} \mathrm{H}_{8}\right), 3,3$-dimethyloxetan (neoC $\mathrm{H}_{10} \mathrm{O}$ ), acetone $\left(\mathrm{CH}_{3} \mathrm{COCH}_{3}\right)$, methane $\left(\mathrm{CH}_{4}\right)$ and formaldehyde $\left(\mathrm{CH}_{2} \mathrm{O}\right)$, which collectively account for at least $95 \%$ of the neopentane consumed [7]. Product formation can be fully explained by the reaction scheme discussed below.

At low fuel conversion, $\beta$-scission of the neopentyl radical leads to the formation of isobutene and methyl radical. This is the primary pathway yielding isobutene with significantly less being produced from the alternative route of $\mathrm{neoC}_{5} \mathrm{H}_{10} \mathrm{OOH} \beta$-scission, reaction (1323). Subsequently, methyl radical will react with molecular hydrogen and to a lesser extent with the fuel, to yield methane and a radical species.

$$
\begin{aligned}
\text { neoC }_{5} \mathrm{H}_{11} & \stackrel{493}{\longrightarrow} \mathrm{iC}_{4} \mathrm{H}_{8}+\mathrm{CH}_{3} \\
\mathrm{CH}_{3}+\mathrm{H}_{2} & \stackrel{-2}{\longrightarrow} \mathrm{CH}_{4}+\mathrm{H} \\
\text { neoC }_{5} \mathrm{H}_{12}+\mathrm{CH}_{3} & \stackrel{487}{\longrightarrow} \text { neoC }_{5} \mathrm{H}_{11}+\mathrm{CH}_{4}
\end{aligned}
$$


The formation of 3,3-dimethyloxetan can be explained exclusively by the reaction.

$$
\mathrm{neoC}_{5} \mathrm{H}_{10} \mathrm{OOH} \stackrel{1322}{\longrightarrow} \text { neoC } \mathrm{C}_{5} \mathrm{H}_{10} \mathrm{O}+\mathrm{OH}
$$

Included in the mechanism are the consumption reactions of $n^{n e o} \mathrm{C}_{5} \mathrm{H}_{10} \mathrm{O}$ :

$$
\begin{aligned}
& \text { neoC }_{5} \mathrm{H}_{10} \mathrm{O} \stackrel{1542}{\longrightarrow} \mathrm{iC}_{4} \mathrm{H}_{8}+\mathrm{CH}_{2} \mathrm{O} \\
& \mathrm{neoC}_{5} \mathrm{H}_{10} \mathrm{O}+\mathrm{X} \longrightarrow \mathrm{tC}_{4} \mathrm{H}_{8} \mathrm{CHO}+\mathrm{HX} \\
& \text { neoC }_{5} \mathrm{H}_{10} \mathrm{O}+\mathrm{X} \longrightarrow \mathrm{iC}_{4} \mathrm{H}_{7}+\mathrm{CH}_{2} \mathrm{O}+\mathrm{HX} \\
& \mathrm{tC}_{4} \mathrm{H}_{8}{ }^{\prime} \mathrm{CHO} \stackrel{1544}{\longrightarrow} \mathrm{iC}_{3} \mathrm{H}_{5} \mathrm{CHO}+\mathrm{CH}_{3} \\
& \mathrm{tC}_{4} \mathrm{H}_{8} \mathrm{CHO} \stackrel{1545}{\longrightarrow} \mathrm{iC}_{4} \mathrm{H}_{8}+\mathrm{HCO}
\end{aligned}
$$

Radical species, such as $\mathrm{H}, \mathrm{OH}$ and $\mathrm{HO}_{2}$ can abstract a $\mathrm{H}$ atom at either of two sites on $\mathrm{neoC}_{5} \mathrm{H}_{10} \mathrm{O}$ :

- a secondary $\mathrm{H}$ atom bonded to the carbon which is part of the ring.

- a primary $\mathrm{H}$ atom bonded to a methyl group.

The more easily abstracted $\mathrm{H}$ atom is that bonded to the carbon in the ring structure, as this carbon atom is bonded to an oxygen atom which is electron withdrawing, and thus lowers the strength of the $\mathrm{C}-\mathrm{H}$ bond. $\mathrm{H}$ atom abstraction is followed by ring opening yielding the $t_{\mathrm{C}_{4}} \mathrm{H}_{8} \mathrm{CHO}$ radical. This $\mathrm{tC}_{4} \mathrm{H}_{8} \mathrm{CHO}$ radical subesquently undergoes $\beta$-scission leading to the formation of isobutene and formyl radical.

Acetone formation results from neoC 5 ket consumption, reaction (1434), which gives the resonantly stabilized radical $\mathrm{iC}_{3} \mathrm{H}_{6} \mathrm{CHO}$, that reacts with molecular oxygen to yield acetone. Acetone also results from a secondary process, the reaction of isobutene with hydroxyl radical through the so-called Waddington mechanism $[25,26]$.

$$
\mathrm{iC}_{3} \mathrm{H}_{6} \mathrm{CHO}+\mathrm{O}_{2} \stackrel{1504}{\longrightarrow} \mathrm{CH}_{3} \mathrm{COCH}_{3}+\mathrm{CO}+\mathrm{OH}
$$




$$
\begin{aligned}
& \mathrm{iC}_{4} \mathrm{H}_{8}+\mathrm{OH} \stackrel{-712}{\longrightarrow} \mathrm{i}, \mathrm{tC}_{4} \mathrm{H}_{8} \mathrm{OH} \\
& \mathrm{i}, \mathrm{tC}_{4} \mathrm{H}_{8} \mathrm{OH}+\mathrm{O}_{2} \stackrel{-706}{\longrightarrow} \mathrm{i}, \mathrm{tO}_{2} \mathrm{C}_{4} \mathrm{H}_{8} \mathrm{OH} \\
& \mathrm{i}, \mathrm{tO}_{2} \mathrm{C}_{4} \mathrm{H}_{8} \mathrm{OH} \stackrel{707}{\longrightarrow} \mathrm{CH}_{3} \mathrm{COCH}_{3}+\mathrm{CH}_{2} \mathrm{O}+\mathrm{OH}
\end{aligned}
$$

It was considered convenient to write the reaction $\mathrm{iC}_{3} \mathrm{H}_{6} \mathrm{CHO}+\mathrm{O}_{2}$ in a concerted way. However, technically this is incorrect as the reaction sequence should proceed as follows:

$$
\begin{aligned}
\mathrm{iC}_{3} \mathrm{H}_{6} \mathrm{CHO}+\mathrm{O}_{2} & \longrightarrow \mathrm{iC}_{3} \mathrm{H}_{6} \mathrm{O}_{2} \mathrm{CHO} \\
\mathrm{iC}_{3} \mathrm{H}_{6} \mathrm{O}_{2} \mathrm{CHO} & \longrightarrow \mathrm{iC}_{3} \mathrm{H}_{6} \mathrm{O}_{2} \mathrm{HCO} \\
\mathrm{iC}_{3} \mathrm{H}_{6} \mathrm{O}_{2} \mathrm{HCO} & \longrightarrow \mathrm{CH}_{3} \mathrm{COCH}_{3}+\mathrm{CO}+\mathrm{OH}
\end{aligned}
$$

The rate of this "concerted" reaction was taken to equal that for $\mathrm{CH}_{2} \mathrm{CHO}+\mathrm{O}_{2}=\mathrm{CH}_{2} \mathrm{O}+\mathrm{CO}+\mathrm{OH}$, $1.81 \times 10^{10}$ reported by Baulch et al. [27] at $300 \mathrm{~K}$ with a temperature dependence added to allow a reasonable reaction rate to be calculated over a broad range of temperature.

\section{Secondary Product Formation}

The initial minor products include, 2,2-dimethyloxiran $\left(\mathrm{iC}_{4} \mathrm{H}_{8} \mathrm{O}\right)$, isobuteraldehyde $\left(\mathrm{iC}_{3} \mathrm{H}_{7} \mathrm{CHO}\right), 2$ methylprop-2-en-1-al $\left(\mathrm{iC}_{3} \mathrm{H}_{5} \mathrm{CHO}\right)$, 2-methylprop-2-en-1-ol $\left(\mathrm{iC}_{4} \mathrm{H}_{7} \mathrm{OH}\right)$, prop-2-en-1-ol $\left(\mathrm{C}_{3} \mathrm{H}_{5} \mathrm{OH}\right)$ and propene $\left(\mathrm{C}_{3} \mathrm{H}_{6}\right)$. Baldwin et al. [21] report that at all concentrations used, the total molar concentration of the minor products accounted for $<5 \%$ of the neopentane consumed at $10 \%$ reaction. They further state that the relative yield of these products increased noticeably as the neopentane was consumed in the early stages of reaction, suggesting that they were mostly formed from secondary processes.

The modelling results are consistent with the observations made by Baldwin et al., and show that almost all of secondary products formed are as a result of isobutene oxidation. For instance, . the main route forming the secondary product $\mathrm{iC}_{4} \mathrm{H}_{8} \mathrm{O}$ is through the chemically activated reaction:

$$
\mathrm{iC}_{4} \mathrm{H}_{8}+\mathrm{HO}_{2} \stackrel{711}{\longrightarrow} \mathrm{iC}_{4} \mathrm{H}_{8} \mathrm{O}+\mathrm{OH}
$$


whose rate was obtained from Baldwin et al. [28], with significantly less $\mathrm{iC}_{4} \mathrm{H}_{8} \mathrm{O}$ being formed through the reaction:

$$
\mathrm{tC}_{4} \mathrm{H}_{8} \mathrm{O}_{2} \mathrm{H}-\mathrm{i} \stackrel{794}{\longrightarrow} \mathrm{iC}_{4} \mathrm{H}_{8} \mathrm{O}+\mathrm{OH}
$$

Formation of isobuteraldehyde is explained by the isomerization of 2,2-dimethyloxetan. The rate of this reaction was taken from Flowers and Parker [29].

$$
\mathrm{iC}_{4} \mathrm{H}_{8} \mathrm{O} \stackrel{1541}{\longrightarrow} \mathrm{iC}_{3} \mathrm{H}_{7} \mathrm{CHO}
$$

It should be noted that the resonantly stabilized radical $\mathrm{iC}_{3} \mathrm{H}_{6} \mathrm{CHO}$ can abstract a $\mathrm{H}$ atom from stable species such as fuel, isobutene or molecular hydrogen or from hydroperoxide radical, leading to the formation of isobuteraldehyde. However, it was found in this study that these reactions did not make a significant contribution to the formation of $\mathrm{iC}_{3} \mathrm{H}_{7} \mathrm{CHO}$. Model predictions indicate that almost all of the $\mathrm{iC}_{3} \mathrm{H}_{6} \mathrm{CHO}$ formed reacts with molecular oxygen producing acetone, carbon monoxide and hydroxyl radical.

The current model underpredicts isobuteraldehyde formation by about a factor of two, indicating that there must be alternative pathways leading to its formation. It could also be argued that the species $\mathrm{iC}_{4} \mathrm{H}_{8} \mathrm{O}_{2} \mathrm{H}-\mathrm{t}$ or $\mathrm{iC}_{4} \mathrm{H}_{9} \mathrm{O}_{2}$ could lead to the formation of isobuteraldehyde. These pathways are speculative and have not been included at present.

Methacrolein, $\mathrm{iC}_{3} \mathrm{H}_{5} \mathrm{CHO}$, formation can be explained primarily by the decomposition of the hydroperoxy-neopentyl species, $n^{2} \mathrm{C}_{5} \mathrm{H}_{10} \mathrm{OOH}$, through the following sequence of reactions:

$$
\begin{aligned}
\text { neoC }_{5} \mathrm{H}_{10} \mathrm{OOH} & \stackrel{1467}{\longrightarrow} \mathrm{iC}_{4} \mathrm{H}_{7} \mathrm{OOH}+\mathrm{CH}_{3} \\
\mathrm{iC}_{4} \mathrm{H}_{7} \mathrm{OOH} & \stackrel{1468}{\longrightarrow} \mathrm{iC}_{4} \mathrm{H}_{7} \mathrm{O}+\mathrm{OH} \\
\mathrm{iC}_{4} \mathrm{H}_{7} \mathrm{O} & \stackrel{1543}{\longrightarrow} \mathrm{iC}_{3} \mathrm{H}_{5} \mathrm{CHO}+\mathrm{H}
\end{aligned}
$$

It is also formed to a lesser extent later in the reaction process through the consumption of 
3,3-dimethyloxetán.

$$
\begin{array}{r}
\text { neoC }_{5} \mathrm{H}_{10} \mathrm{O}+\mathrm{X} \longrightarrow \mathrm{tC}_{4} \mathrm{H}_{8} \mathrm{CHO}+\mathrm{HX} \\
\mathrm{tC}_{4} \mathrm{H}_{8} \mathrm{CHO} \stackrel{1544}{\longrightarrow} \mathrm{iC}_{3} \mathrm{H}_{5} \mathrm{CHO}+\mathrm{CH}_{3}
\end{array}
$$

The formation of 2-methylprop-2-en-1-ol, $\mathrm{iC}_{4} \mathrm{H}_{7} \mathrm{OH}$, can be explained through the consumption of the $\mathrm{iC}_{4} \mathrm{H}_{7} \mathrm{O}$ species. As has already been illustrated above $\mathrm{iC}_{4} \mathrm{H}_{7} \mathrm{O}$ can undergo $\beta$-scission losing a $\mathrm{H}$ atom to produce methacrolein but it can also undergo an internal hydrogen abstraction producing the more stable $\mathrm{iC}_{3} \mathrm{H}_{6} \mathrm{OH}$ radical species.

$$
\mathrm{iC}_{4} \mathrm{H}_{7} \mathrm{O} \stackrel{1520}{\rightleftharpoons} \mathrm{iC}_{3} \mathrm{H}_{6} \mathrm{OH}
$$

This species is very similar to the allyl radical and as such can behave in much the same way as an allyl radical abstracting a $\mathrm{H}$ atom from other species to produce $\mathrm{iC}_{4} \mathrm{H}_{7} \mathrm{OH}$.

Alternatively, the resonantly stabilized radical $\mathrm{iC}_{4} \mathrm{H}_{6} \mathrm{OH}$ can react with $\mathrm{HO}_{2}$ radical leading through the following reaction sequence to the formation of the xsecondary product prop-2-en-1-ol.

$$
\begin{aligned}
\mathrm{iC}_{4} \mathrm{H}_{6} \mathrm{OH}+\mathrm{HO}_{2} \stackrel{1552}{\longrightarrow} \mathrm{CH}_{2} \mathrm{CCH}_{2} \mathrm{OH}+\mathrm{CH}_{2} \mathrm{O}+\mathrm{OH} \\
\mathrm{CH}_{2} \mathrm{CCH}_{2} \mathrm{OH}+\mathrm{HX} \longrightarrow \mathrm{C}_{3} \mathrm{H}_{5} \mathrm{OH}+\mathrm{X}
\end{aligned}
$$

One pathway considered was the reaction sequence:

$$
\mathrm{iC}_{4} \mathrm{H}_{7} \mathrm{O}+\mathrm{HX} \longrightarrow \mathrm{iC}_{4} \mathrm{H}_{7} \mathrm{OH}+\mathrm{X}
$$

in which isobutenylalkoxy radical can abstract a $\mathrm{H}$ atom from a stable molecule producing 2methylprop-2-en-1-ol. It was found that this reaction was less important than either the $\beta$-scission reaction or the internal isomerization.

Finally, propene was found to be formed through the reaction of isobutene with $\mathrm{H}$ atom and with hydroxyl radical through the $\mathrm{C}_{3}$ alkylhydroperoxide species as follows.

$$
\mathrm{iC}_{4} \mathrm{H}_{8}+\mathrm{H} \stackrel{1534}{\longrightarrow} \mathrm{C}_{3} \mathrm{H}_{6}+\mathrm{CH}_{3}
$$




$$
\begin{aligned}
\mathrm{iC}_{4} \mathrm{H}_{8}+\mathrm{OH} & \stackrel{215}{\longrightarrow} \mathrm{iC}_{3} \mathrm{H}_{7}+\mathrm{CH}_{2} \mathrm{O} . \\
\mathrm{iC}_{3} \mathrm{H}_{7} \mathrm{O}_{2} & \stackrel{674}{\longrightarrow} \mathrm{iC}_{3} \mathrm{H}_{7}+\mathrm{O}_{2} \\
\mathrm{iC}_{3} \mathrm{H}_{7} \mathrm{O}_{2} & \stackrel{634}{\longrightarrow} 2-\mathrm{C}_{3} \mathrm{H}_{6} \mathrm{OOH}-1 \\
2-\mathrm{C}_{3} \mathrm{H}_{6} \mathrm{OOH}-1 & \stackrel{597}{\longrightarrow} \mathrm{C}_{3} \mathrm{H}_{6}+\mathrm{HO}_{2}
\end{aligned}
$$

\section{Conclusions}

A detailed chemical kinetic model has been developed to treat neopentane oxidation. Calculations on a limited set of experimental results have shown that the model can predict both primary and secondary product formation with a high degree of accuracy.

Baker et al. [7] had previously argued that the formation of the minor products takes place by methyl group transfer and a bi-radical intermediate. This study has shown that with present knowledge of low-temperature oxidation systems it is possible to explain minor product formation in a more conventional manner.

It is apparent from analysis of both primary and to a larger degree secondary product formation that oxidation chemistry of neopentane depends to a large degree on the oxidation of isobutene. Almost all of the secondary product formation can be explained by its oxidation.

It could also be concluded that the high Research Octane Number (RON) of neopentane (86) may be in some part due to the fact that one of the main primary products is isobutene, which has a high RON of 106.

\section{Acknowledgement}

This work was performed under the auspices of the U.S. Department of Energy by the Lawrence Livermore National Laboratory under contract No. W-7405-ENG-48. 


\section{References}

[1] Cox, R. A., Modern Gas Kinetics. eds. M. J. Pilling and I. W. M. Smith (Blackwell, Oxford, 1987) pp. 262.

[2] Zeelenberg, A. P., Rec. Trav. Chim., 81:720 (1962).

[3] Antonik, S. and Lucquin, M., Bull. Soc. Chim., 2796, (1968).

[4] Antonik, S. and Lucquin, M., Bull. Soc. Chim., 3139, (1971).

[5] Drysdale, D. D. and Norrish, R. G. W. proc. Roy. Soc. A308, 305-325 (1969).

[6] Fish, A., Combust. Flame 14:23-32 (1969).

[7] Baker, R. R.; Baldwin, R. R.; Everett, C. J. and Walker, R. W., Combust. Flame 25:285-300 (1975).

[8] Baker, R. R.; Baldwin, R. R. and Walker, R. W., Combust. Flame 27:147-161 (1976).

[9] Lund, C. M. and Chase, L., "HCT - A General Computer Program for Calculating TimeDependent Phenomena Involving One-Dimensional Hydrodynamics, Transport, and Detailed Chemical Kinetics," Lawrence Livermore National Laboratory report UCRL-52504, revised (1995).

[10] Westbrook, C. K., Warnatz, J., and Pitz, W. J., Twenty-Second Symposium (International) on Combustion., pp. 893-901, The Combustion Institute, Pittsburgh, 1988.

[11] Westbrook, C. K., Pitz, W. J., and Leppard, W. R., Society of Automotive Engineers publication SAE-912314 (1991).

[12] Chevalier, C., Pitz, W. J., Warnatz, J., Westbrook, C. K., and Melenk, H., Twenty-Fourth Symposium (International) on Combustion., pp. 92-101, The Combustion Institute, Pittsburgh, 1992.

[13] Westbrook, C. K., and Pitz, W. J., Western States Section/ The Combustion Istitute (1993). 
[14] Curran, H. J., Gaffuri, P., Pitz, W. J., Westbrook, C. K., Callahan, C., Dryer, F. L., and Held, T., Central States/Western States/Mexican Ntl. Sections Comb. Inst. 263, (1995).

[15] Ritter, E. R. and Bozzelli, J. W., Int. J. Chem. Kinet. 23:767 (1991).

[16] Lay, T. and Bozzelli, J. W., Chemical and Physical Processes in Combustion, The Eastern States Section of the Combustion Institute, Paper \# 100 (1-4), (1993).

[17] Xi, Z.; Han, W-J and Bayes, K. D., J. Phys. Chem. 92:3450 (1988).

[18] Slagle, I. R.; Batt, L; Gmurczyk, G. W.; Gutman, D. and Tsang, W., J. Phys. Chem. 95:7732-7739 (1991)

[19] Hughes, K. J.; Lightfoot, P. D. and Pilling, M. J., Chem. Phys. Lett. 191:581-586 (1992).

[20] Hughes, K. J.; Halford-Maw, P. A.; Lightfoot, P. D.; TurÁnyi, T, and Pilling, M. J., TwentyFourth Symposium (International) on Combustion., pp. 645-652, The Combustion Institute, Pittsburgh, 1992.

[21] Baldwin, R. R.; Hisham, M. W. M. and Walker, R. W., J. Chem. Soc. Farad. Trans.1, 78:1615-1627 (1982).

[22] Pollard, R. T., Comprehensive Chemical Kinetics, (C. H. Bamford and C. F. H. Tipper, Eds), Elsevier, New York, Vol. 17, p. 249, 1977,

[23] Sahetchian, K. A., Rigny, R., and Circan, S., Combust. Flame 85:511-514 (1991).

[24] Sahetchian, K. A.; Heiss, A.; Rigny, R. and Ben-Aim, R. I., J. Chem. Kinet. 14:1325-1337 (1982).

[25] Ray, D. J. M.; Diaz, R. R. and Waddington, D. J., Fourteenth Symposium (International) on Combustion., pp. 259, The Combustion Institute, Pittsburgh, 1973.

[26] Ray, D. J. M. and Waddington, D. J., Combust. Flame 20:327 (1973).

[27] Baulch, D. L.; Cobos, C. J.; Cox, R. A.; Esser, C.; Frank, P.; Just, Th.; Kerr, J. A.; Pilling, M. J.; Troe, J; Walker, R. W.; Warnatz, J. J. Phys. Chem. Ref. Data 21:411-429 (1992). 
[28] Baldwin, R. R.; Dean, C. E., and Walker, R. W., J. Chem. Soc. Farad. Trans.2, 82:1445-1455 (1986).

[29] Flowers, M. C. and Parker, R. M. Intl. J. Chem. kinet. 3:443 (1971).

[30] Pitz, W. J.; Westbrook, C. K. and Leppard, W. R., Society of Automotive Engineers publication SAE-912315 (1991).
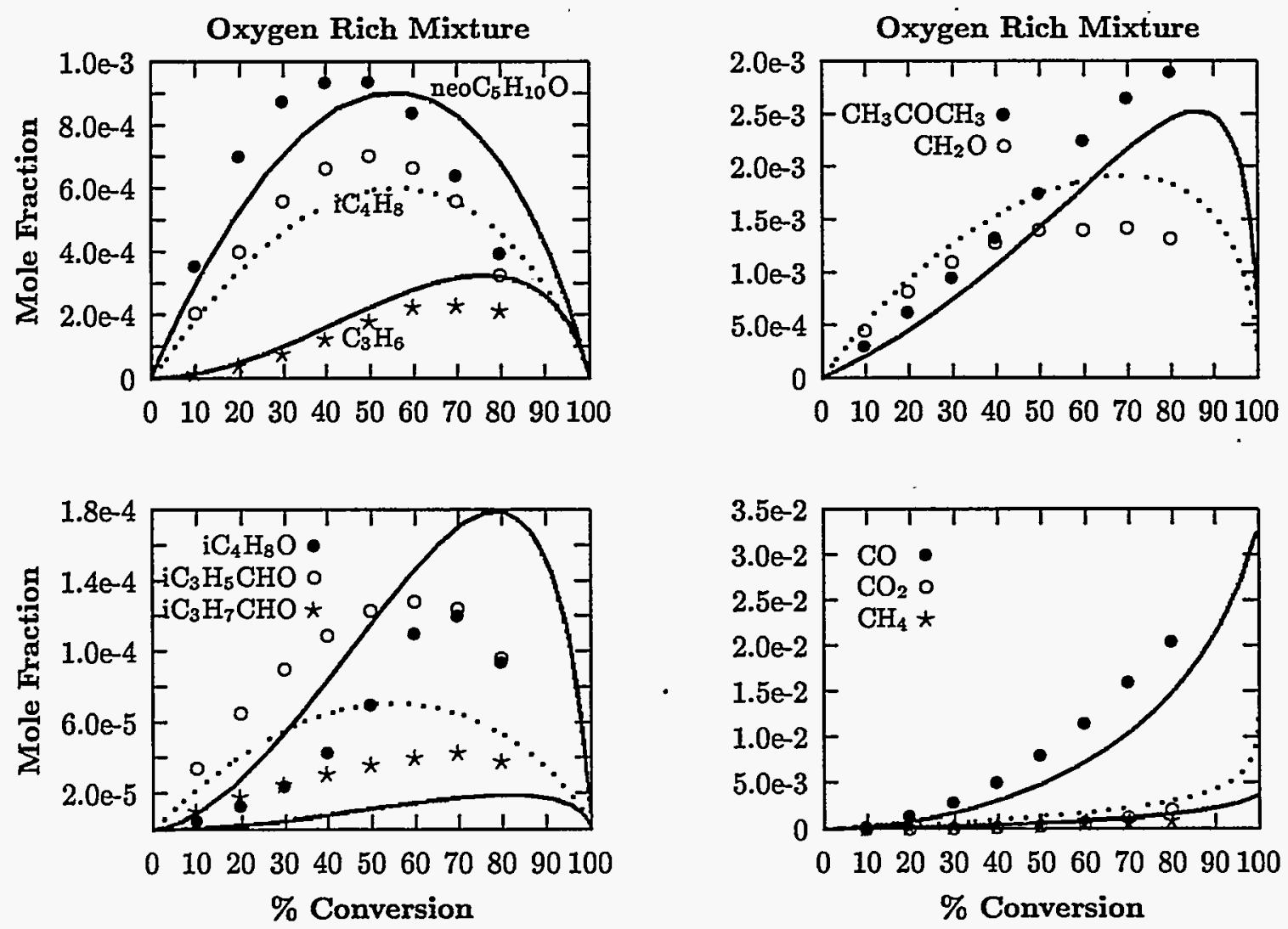

Figure 1: Experimental results (points) [7] vs model predictions (lines) for neopentane oxidation. Dotted lines correspond to open circles. 
Hydrogen Rich Mixture
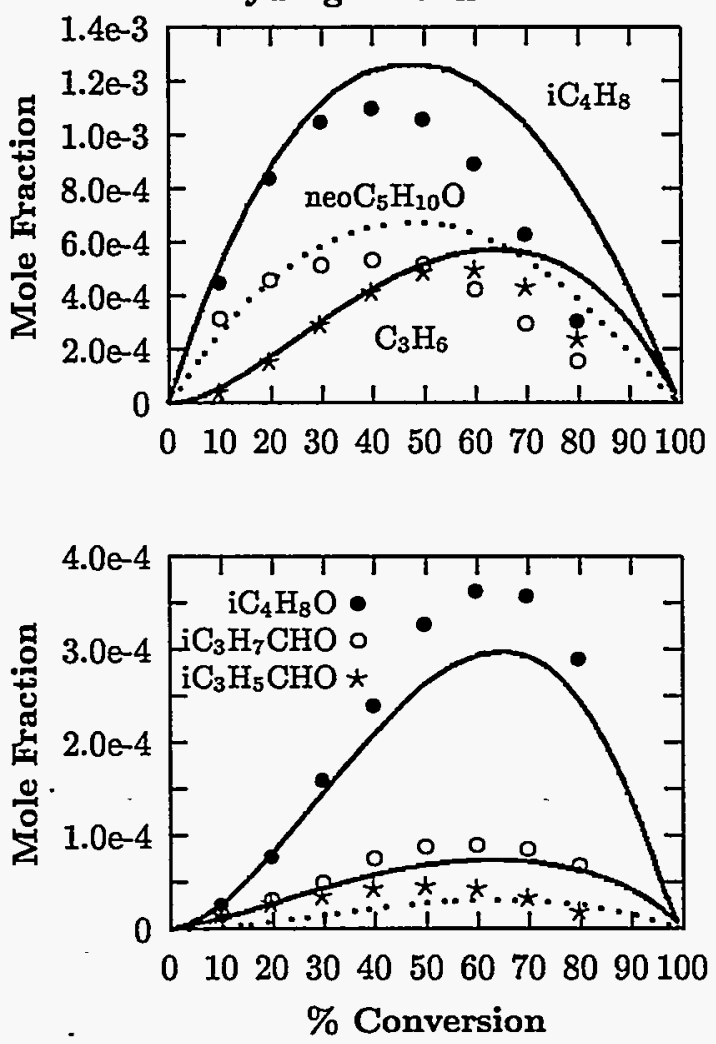

Hydrogen Rich Mixture
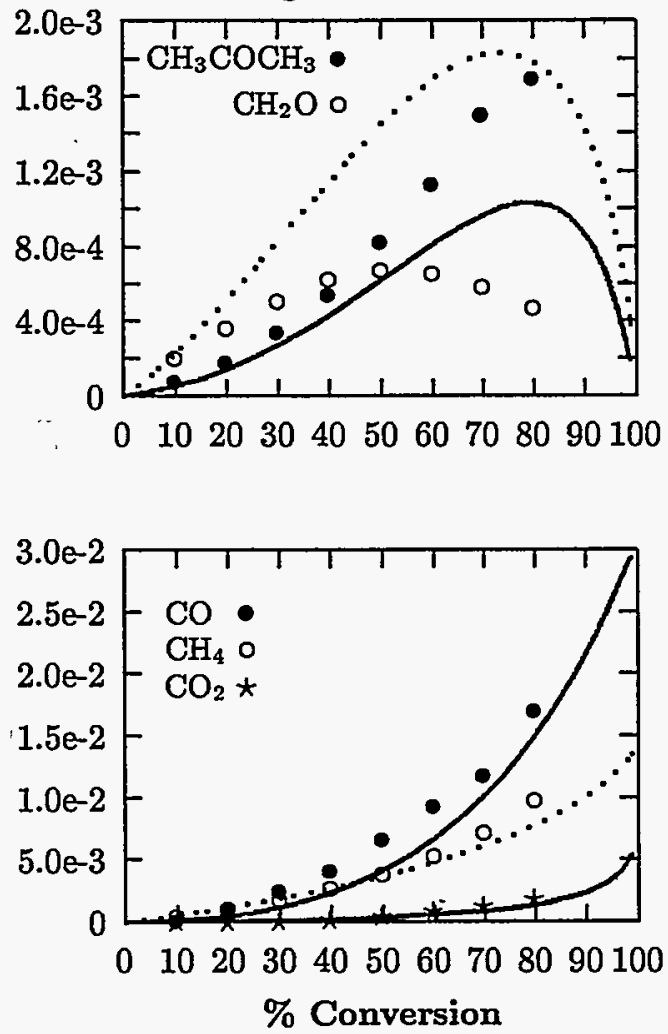

Figure 2: Experimental results (points) [7] vs model predictions (lines) for neopentane oxidation. Dotted lines correspond to open circles. 



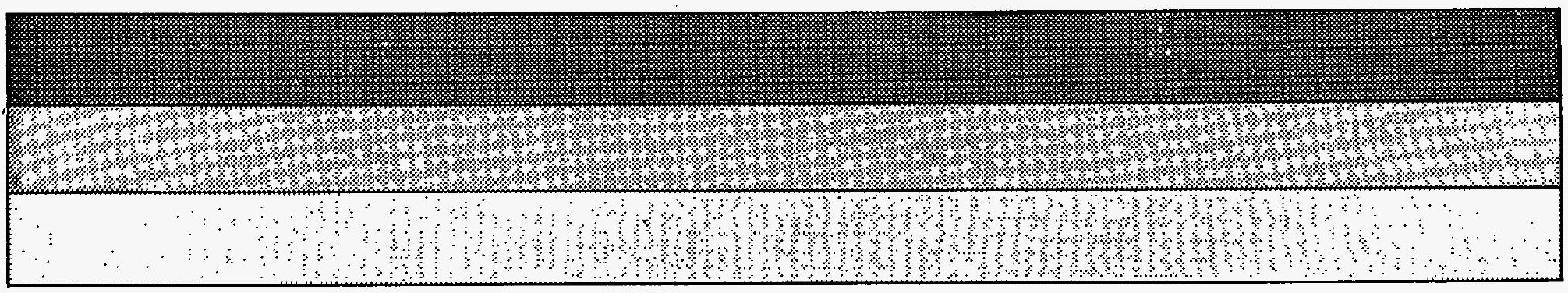

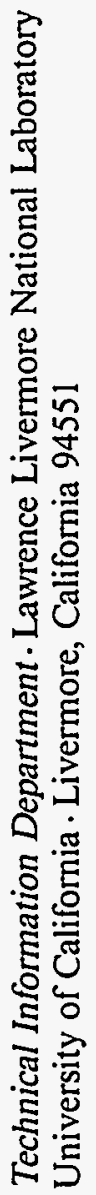

